\title{
Preventing crop raiding by the Vulnerable common hippopotamus Hippopotamus amphibius in Guinea-Bissau
}

\author{
Luis M. González, Francisco G. D. Montoto, Tome Mereck, Junior Alves \\ José Pereira, Pablo Fernández de Larrinoa, Ana Maroto \\ Luis Bolonio and NuRia El-KadHiR
}

\begin{abstract}
Guinea-Bissau is host to the westernmost subpopulation of the common hippopotamus Hippopotamus amphibius, which is one of only two known populations inhabiting coastal waters. The presence of hippopotamuses causes conflict with rice farmers as a result of crop damage and the absence of effective measures to protect crops. To develop an effective method for protecting rice fields, we studied the patterns of access to flooded and rain-fed rice fields by hippopotamuses and assessed the effect of the installation of electric fences. Hippopotamuses were detected in $54 \%$ of the flooded fields $(\mathrm{n}=100)$ and in $31.9 \%$ of the rain-fed fields $(n=91)$. They were detected more frequently in fields on offshore islands than on the mainland, in unfenced than in fenced fields, and in fields closer to running water. Hippopotamuses entered fenced flooded fields less frequently than unfenced, and were detected most frequently at the end of the rainy season and the start of the dry season, and in the period of vegetative stem growth. Electric fences were an effective deterrent and facilitated increased rice production. The maintenance and cost of the electric fencing were acceptable to farmers, and therefore the use of such fencing is recommended to resolve the conflict between hippopotamuses and farmers in Guinea-Bissau and in other areas with similar conditions.
\end{abstract}

Keywords Common hippopotamus, crop raiding, electric fence, Guinea-Bissau, Hippopotamus amphibius, human-wildlife conflict, rice fields

\section{Introduction}

rop raiding by wild animals results in substantial financial losses for farmers living in proximity to wildlife. When wildlife is protected, traditional means of crop

Luis M. González (Corresponding author) and Francisco G. D. Montoto Subdirección General de Medio Natural, Ministerio de Medio Ambiente, Plaza San Juan de la Cruz s/n, Madrid 28071, Spain

E-maillmgonzalez@magrama.es

Tome Mereck, Junior Alves, José Pereira, Pablo Fernández de Larrinoa, Ana Maroto, Luis Bolonio and Nuria El-Kadhir Fundación CBD-Hábitat, Madrid, Spain

Received 2 June 2015. Revision requested 20 July 2015.

Accepted 26 August 2015. First published online 26 January 2016. protection, such as killing the wild animals involved in crop raiding, are limited, and thus human-wildlife conflict jeopardizes the efficacy of protected areas by undermining local support for conservation (Fungo, 2011). To resolve the conflict, wildlife managers usually mitigate the crop raiding activities of wild animals; for example, by scaring animals away from crops, using scare-shooting and barriers, or compensating farmers for crop loss. However, the latter measure, particularly when it involves cash payments, is open to corruption and some farmers may be less likely to improve their management practices or adopt new ones to reduce conflict. Thus, bad managers may be compensated at the expense of those who invest in good management techniques on their own initiative (Woodroffe et al., 2005; Fungo, 2011).

The common hippopotamus Hippopotamus amphibius, categorized as Vulnerable on the IUCN Red List (Lewison \& Oliver, 2008), is a major source of human-wildlife conflict in Africa. It causes damage to crops and attacks people (Mkanda, 1994; Kendall, 2011). The decline of the species has been attributed to killing of hippopotamuses by farmers, and the loss of grazing grounds as a result of agricultural development (Eltringham, 1999; Lewison \& Oliver, 2008).

The hippopotamus population in Guinea-Bissau is the westernmost population (Eltringham, 1999) and is one of only two known populations to use seawater and inhabit coastal areas (the other is the subpopulation in Loango National Park, Gabon; Limoges \& Robillard, 1991; Michez, 2006). During the 2oth century the hippopotamus became rare in Guinea-Bissau, where it was considered to be a game species. The decline has been linked to shooting of hippopotamuses in retaliation for crop damage; for example, in the region of Cacheu during 1975-1996 29 hippopotamus deaths resulted from conflict with farmers (Lopes, 1998). In 1996-1997 the hippopotamus was declared a protected species in Guinea-Bissau and two protected areas with hippopotamus populations were established: Orango National Park and Cacheu Natural Park (IBAP, 2014). There are estimated to be c. 50 individuals in Cacheu, 135-150 in Orango and 60-65 in the areas of Bissorao and Carantaba (Lopes, 1998; Silva \& Monteiro, 2006; IBAP, 2008; Silva, 2008).

Hippopotamuses require large areas of savannah grasslands, where they feed on stems of herbaceous species, and in times of food stress they will also feed in cultivated 


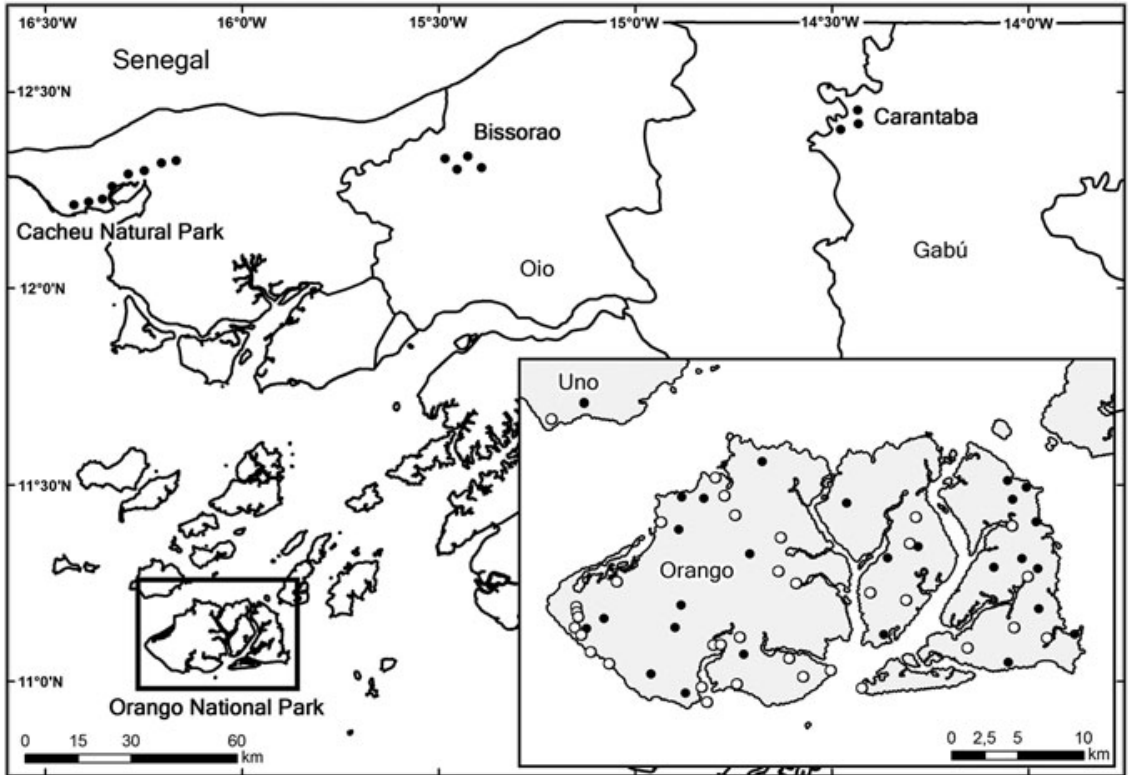

FIG. 1 Locations of the rice fields (black filled circles) studied in Cacheu Natural Park, Bissorao and Carantaba, on mainland Guinea-Bissau, and in the Orango Islands National Park and Uno Island, with the hippopotamus Hippopotamus amphibius resting places (filled white circles) identified in previous studies (Silva, 2008). rice fields if available (Eltringham, 1999; Kendall, 2011). Rice production is one of the main economic activities of the rural population of Guinea-Bissau and is the most important livelihood activity for people in the protected areas of Orango and Cacheu (Alves \& Barros, 1997; Medina, 2008). Past surveys with farmers in Guinea-Bissau showed that hippopotamuses were responsible for a significant reduction in rice production and caused significant economic losses (Lopes, 1998; Medina, 2008; Silva, 2008). They also have indirect effects, such as restricting people's movements and causing accidents and deaths. In the 2 oth century 42 people were injured and 12 killed by hippopotamuses in Orango and Cacheu as a result of boat sinking or while guarding rice fields, and hippopotamuses are thus widely perceived to be one of the major threats to the security and livelihoods of rural people, and inspire animosity and fear (Lopes, 1998; Campos et al., 2001; IBAP, 2008). Consequently the rice fields situated near water courses inhabited by hippopotamuses have progressively been abandoned in favour of rice fields located within forested areas, and this is contributing to increases in deforestation and biodiversity loss (Vasconcelos et al., 2002; Medina, 2008).

To prevent hippopotamuses from entering rice fields, farmers in Guinea-Bissau have been using barbed-wire fences, embankments and ditches, and night watchmen with fires and weapons. However, because of their high cost, complex maintenance or safety hazards these methods have not been successful (Lopes, 1998; Campos et al., 2001; Silva \& Monteiro, 2006; Medina, 2008). Electric fencing, which is used effectively in other countries (Eltringham, 1999), has not been previously tested in Guinea-Bissau. Although farmers in protected areas have requested compensation, or elimination of hippopotamuses, the wildlife authorities have not considered either option. Compensation is not sustainable, and shooting has not been effective in minimizing crop damage in other countries with similar problems (Mkanda, 1994; Fungo, 2011), and may cause hippopotamuses to become more aggressive (Eltringham, 1999). The hippopotamus is a charismatic species that attracts tourists and has the potential to generate significant foreign currency income. In this context the management plans of Orango and Cacheu protected areas, developed in consultation with local people, prioritize the assessment of mitigation measures to resolve the conflict (Campos et al., 2001; IBAP, 2008).

The behaviour of hippopotamuses in response to protection measures has not been well studied (Eltringham, 1999). To address human-hippopotamus conflict it is necessary to consider both the patterns and effects of the damage as well as the impacts of mitigating actions on the conservation status of the hippopotamus. With the aim of contributing to resolving the conflict between hippopotamuses and rice farmers in Guinea-Bissau, we investigated access to rice fields, and evaluated the effectiveness of a protective measure (electric fencing), hippopotamus behaviour in response to this measure, and the feasibility of its use by local farmers. We propose practical and feasible measures to solve the conflict between people and hippopotamuses.

\section{Study area}

The study was conducted in the Orango Islands National Park (26,00o ha; IBAP, 2014) and Uno Island in the Bijagos archipelago, in Cacheu Natural Park (94,80o ha; IBAP, 2014), in Bissorao in the region of Oio, and in Carantaba in the region of Gabu (Fig. 1). Henceforth the term Orango includes Uno Island. 
The climate is tropical, with a rainy season during May-October in the Bijagos and during June-October on the mainland. The dry season is December-April in the Bijagos and December-May on the mainland. The mean annual rainfall is $2,000 \mathrm{~mm}$ in the Bijagos and $1,400-1,800$ $\mathrm{mm}$ on the mainland, and the mean annual temperature is $26.1^{\circ} \mathrm{C}$; both parameters were stable during the study period, with no drought years (Medina, 2008; CCKP, 2015).

The dominant vegetation in the study area consists of a mosaic of tropical dry forest and tree and shrub dry savannah, with sub-humid isolated and flooded herbaceous savannah (Catarino et al., 2008). Two types of rice fields were included in the study: flooded and rain-fed. The flooded fields, known locally as bolanha and bas-fond, are flooded by river run-off and are located in the humid savannah and alluvial depressions. The water is retained and regulated by a system of dykes with drainage channels. Management is communal, with each field divided into owned plots (Biai, 2000; Medina, 2008). The long-cycle rice seed (120-day seed) and occasionally the short-cycle seed (90-day seed) are used. Sowing begins after water reaches the maximum retainable level, and the rice growth depends on the amount of water available in the soil. The duration of the crop in each area varies depending on when the rainy season begins (Medina, 2008). In Orango, during the study period, sowing began in July-August and harvesting in December-January; in Cacheu, sowing started in June-July and harvesting in December; and in Bissorao and Carantaba, sowing began in August-September and harvesting in December-January.

The rain-fed fields, known locally as mpam-mpam, are located in non-flooded lands, in forested areas where the vegetation was previously slashed and burned. Each year a different area of land is prepared, and the same area is cultivated again every 9-10 years. The short-cycle seeds are used most often in these fields. The water comes exclusively from rainfall, and crop development conforms to the duration of the rainy season. Sowing normally begins in April-May and harvesting in October-November (Biai, 200o; Medina, 2008).

\section{Methods}

\section{Monitoring of rice fields}

We conducted enquiries with farmers in Orango in 2008 $(\mathrm{n}=179)$ and on the mainland in $2012(\mathrm{n}=248)$ to locate rice fields and record their state of cultivation. Subsequently we identified farmers with flooded fields who were willing to collaborate with the study and consented to the installation of electric fences, and monitoring of their fields. During 2008-2011 in Orango and 2012-2013 on the mainland we monitored 75 flooded fields with electric fences, 25 unfenced flooded fields and 91 unfenced rain-fed fields (Table 1). We recorded the location and area of each rice field using a global positioning system to an accuracy of $5 \mathrm{~m}$. We also measured the distance of each field to the nearest running water. All fields were unguarded by night watchmen during the study period. The number of fenced fields increased each year. The electric fence equipment was retired each year after the end of the harvest and installed again the following year in the same field, until the end of the study period. During the period of rice cultivation each year, the perimeter and interior of fenced fields was monitored daily by the farmers. In addition, we surveyed the fenced and unfenced fields every $3-4$ days during this period to search for hippopotamus footprints. Information on hippopotamus presence in rain-fed fields was provided by farmers at the end of the growing season, having been verified by protected area wardens.

We recorded hippopotamus detection without entry if we observed footprints only on the perimeter, and with entry if the footprints were in the interior of the field. The location and date were recorded for each footprint, to avoid duplication. The hippopotamus populations of Orango and Cacheu are isolated and, according to annual monitoring by wardens, hippopotamuses occupied the same areas during the study period as in previous studies (Lopes, 1998; Silva, 2008; IBAP, 2014; Fig. 1).

We estimated the rice productivity $\left(\mathrm{kg} \mathrm{ha}^{-1}\right)$ in each field by interviewing the farmers and recording the number of bags of rice produced each season (each bag weighing c. $40 \mathrm{~kg}$ ) and the number of families working the fields. In Orango we interviewed 135, 179, 327 and 566 farmers during 2008-2011, respectively; on the mainland we interviewed 494 and 566 farmers in 2012 and 2013, respectively. To avoid overestimation of crop losses, we recorded the area affected, and this information was checked by the wardens of the protected areas.

We identified three periods of rice cultivation (sowing, vegetative shoot growth and harvesting) and five climatic periods (end of the dry season, February-April, $<10 \mathrm{~mm}$ rainfall per month; start of the rainy season, May-June, 10-200 mm per month; full rainy season, July-September, $>200 \mathrm{~mm}$ per month; end of the rainy season, OctoberNovember, 10-200 mm per month; beginning of the dry season, December-January, $<10 \mathrm{~mm}$ per month).

The electric fence system included an aluminium wire of $2.5 \mathrm{~mm}$ diameter, c. $80 \mathrm{~cm}$ above the ground, connected to an energizer unit, and a rope between wooden stakes, with strips of red and white striped plastic at intervals of $1 \mathrm{~m}$ (Plate 1). We used two models of portable energizers with integrated solar panels: Speedrite-Viper S250 (Tru-Test Group, Auckland, New Zealand), which powered c. $4 \mathrm{~km}$

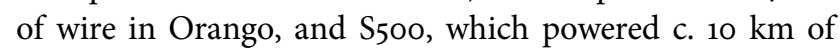
wire on the mainland. In each field two energizers were used simultaneously. The charge was activated and switched 


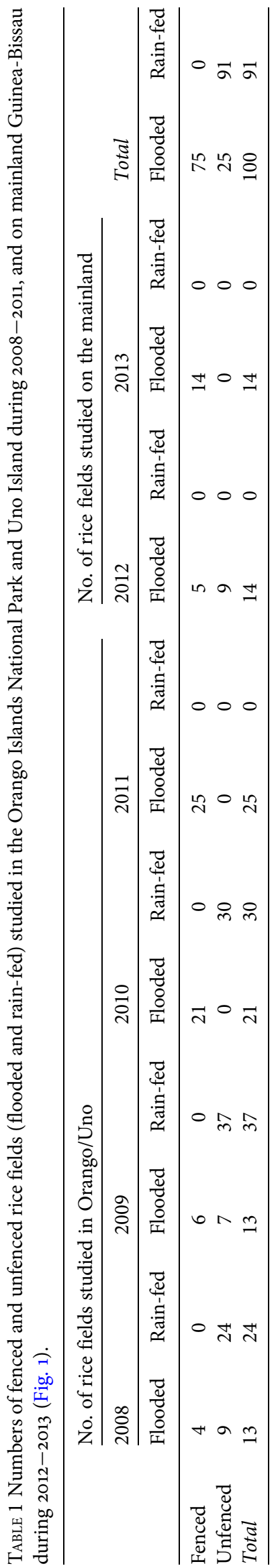

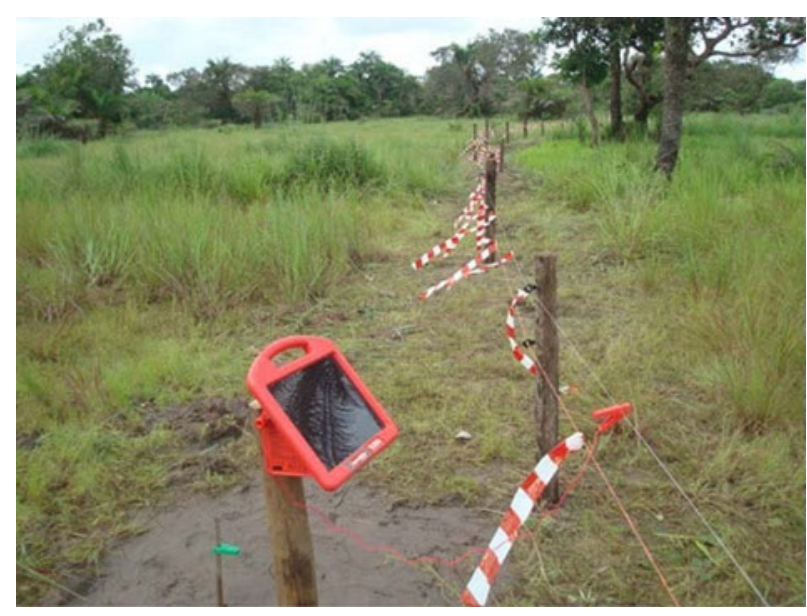

Plate 1 The electric fencing system in a flooded rice field in Orango (Fig. 1), with the energizer unit model S250 with integrated solar panel.

on only at night. The cost of a complete fencing system with the S250 and S500 energizers was c. EUR 650 and 950, respectively. The vegetation was cut from within a distance of $2-3 \mathrm{~m}$ around the wires twice per week.

\section{Variables and statistical analyses}

The rice field was considered to be the experimental unit. To identify differences in the raiding patterns of hippopotamuses we considered two response variables: hippopotamus detection/no detection, and the number of fields where hippopotamuses were detected. We used the following as explanatory variables: the type of field (flooded vs rain-fed); the geographical location of the field (island vs mainland); the distance to the nearest water body (in $\mathrm{m}$ ); the presence/absence of electric fencing; the cultivation phase (sowing, growth or harvesting); and the climatic period. To investigate the economic effects of fencing we used the following as response variables: the rice productivity of the field, the number of families working in the field, and the number of flooded or rain-fed fields. As independent variables we used the presence/absence of electric fencing, and the year.

As quantitative variables could not be fitted to a normal distribution we performed non-parametric analysis, using as covariates each of the independent variables, with a confidence interval of $95 \%$. Based on the characteristics of the response and explanatory variables (categorical or continuous) we performed various tests: frequency analyses $\left(\chi^{2}\right)$ when response and explanatory variables were categorical, simple regression analyses for continuous variables, and Kruskal-Wallis $\left(\chi^{2}\right)$ for comparing mean values of the multiple $(>2)$ categories of independent categorical variables. To compare the mean annual productivity of fields we used the same fields before and after the installation of the 
electric fences (matched pair data), and applied a Wilcoxon test $(Z)$. Only significant results and those that approached significance are presented. The analyses were carried out using Statistica v. 6.1 (StatSoft, 2002).

\section{Results}

\section{Monitoring of rice fields}

In Orango we located 62 flooded rice fields, $74.2 \%$ of them abandoned. The cause of abandonment was known in 30 cases: entry of hippopotamuses was the most frequent cause $(70 \%)$, followed by migration of the human population $(20 \%)$ and low rice production (10\%). In 2007 , the year before electric fences were installed, hippopotamuses had entered four of the 10 flooded fields that were cultivated. On the mainland we located 19 cultivated flooded fields, and in the year before the electric fences were installed (2011) hippopotamuses had entered all of these fields.

Hippopotamuses were detected in $43.5 \%$ of fields $(n=191)$, and the rate of detection was significantly higher in flooded than in rain-fed fields $(54 \%, \mathrm{n}=100$ vs $31.9 \%$, $\left.\mathrm{n}=91, \chi_{1}^{2}=3.79, \mathrm{P}=0.051\right)$. The mean distance of flooded fields to the nearest running water was $735 \mathrm{~m}(2.2-5.0 \mathrm{~m}, \mathrm{n}$ $=40$ ), and the number of flooded fields where hippopotamuses were detected was significantly higher closer to running water $(r=-0.507, \mathrm{P}=0.0008)$.

The number of flooded fields in which hippopotamuses were detected decreased significantly over the study period $\left(r^{2}=0.91, \quad r=-0.95, \quad \mathrm{P}=0.042\right)$, increased significantly with the number of times the field was cultivated $\left(r^{2}=0.58\right.$, $r=0.76, \mathrm{P}<0.001$ ), and was significantly higher in Orango than on the mainland $(85.7 \%, \mathrm{n}=28$ vs $38.9 \%, \mathrm{n}=72$, $\left.\chi_{1}^{2}=4.54, \mathrm{P}=0.039\right)$ and in unfenced vs fenced fields $\left(80.0 \%, \mathrm{n}=25\right.$ vs $\left.45.3 \%, \mathrm{n}=75, \chi_{1}^{2}=2.45, \mathrm{P}=0.058\right)$. The number of fields where entry by hippopotamuses was detected was significantly lower for fenced than unfenced fields $\left(1.3 \%, \mathrm{n}=75\right.$ vs $\left.80.0 \%, \mathrm{n}=25, \chi_{1}^{2}=35.31, \mathrm{P}<0.001\right)$.

In flooded fields we detected hippopotamuses during September-January $(\mathrm{n}=79)$, mostly during October-December (79.7\%). In rain-fed fields we detected hippopotamuses in August and September $(n=6)$. In all areas studied the number of fields where hippopotamuses were detected was significantly higher at the end of the rainy season and at the start of the dry season than at other times $\left(\chi_{4}^{2}=30.51, \mathrm{P}<0.001\right.$; Fig. 2$)$, and during the period of vegetative stem growth than during sowing and harvest $\left(\chi_{2}^{2}=6.00, \mathrm{P}=0.049\right.$; Fig. 3$)$.

\section{Area and productivity of rice fields}

The area of flooded fields was $0.22-21.09$ ha in Orango and 7.9-321.2 ha on the mainland. The total area and the

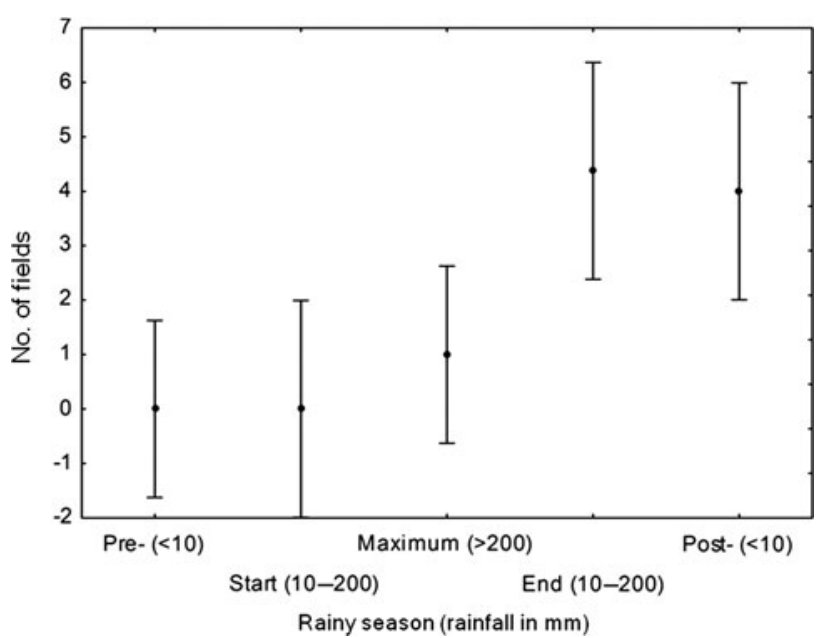

FIG. 2 Mean number of flooded rice fields (with 95\% confidence intervals) in the study areas in Guinea-Bissau (Fig. 1) where hippopotamuses were detected at various periods before, during and after the rainy season.

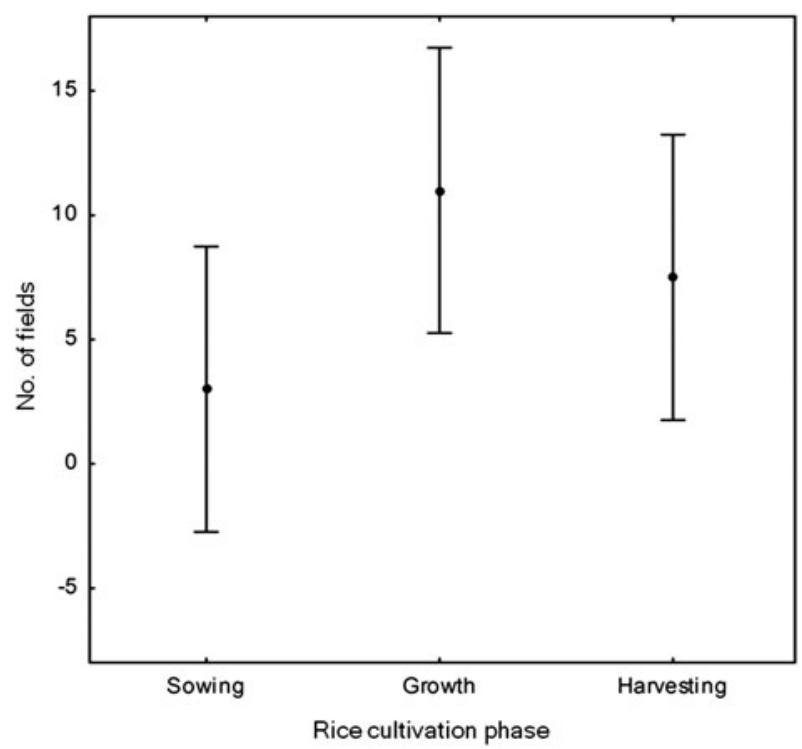

FIG. 3 Mean number of flooded rice fields (with 95\% confidence intervals) in the study areas in Guinea-Bissau (Fig. 1) where hippopotamuses were detected during various stages of crop development.

number of cultivated flooded fields increased significantly during the study (42.83 ha in 2007, $\mathrm{n}=10$; 109.34 ha in 2011, $\left.\mathrm{n}=25 ; r^{2}=0.82, r=0.90, \mathrm{P}=0.094\right)$ and consequently rice production increased (from $3,568 \mathrm{~kg}$ in 2007 to 94,126 $\mathrm{kg}$ in 2011). The mean productivity increased significantly after the installation of the electric fencing ( 946.3 vs 730.0 $\mathrm{kg} \mathrm{ha}^{-1}, \mathrm{n}=21 ; Z=2.09, \mathrm{P}=0.036, \mathrm{n}=20$ ).

The area of rain-fed fields in Orango decreased (103.97 ha in $2009, \mathrm{n}=37 ; 43.41$ ha in 2010, $\mathrm{n}=30$ ), although not significantly $\left(r^{2}=0.77, r=-0.89, \mathrm{P}=0.288\right)$. The number of families working in fenced fields in Orango increased 


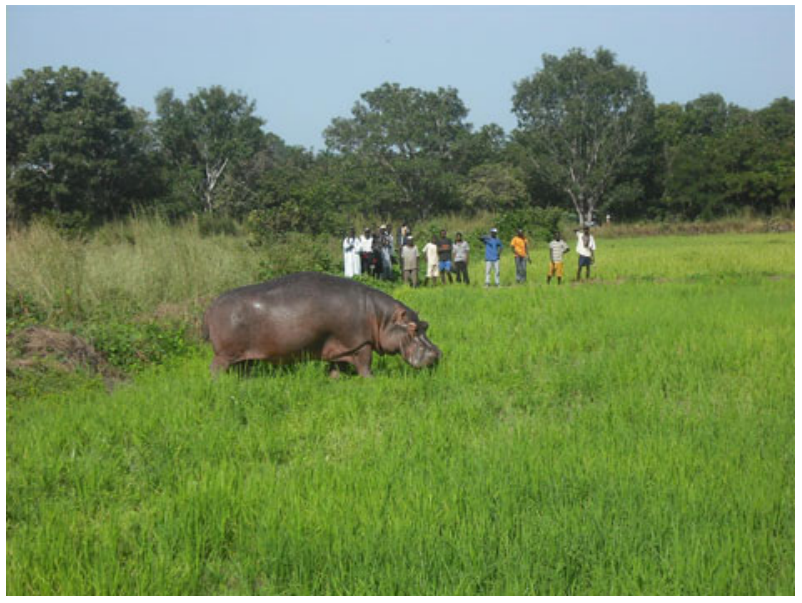

Plate 2 A hippopotamus Hippopotamus amphibius feeding in a flooded rice field in Carantaba, observed by local people. (Photograph by Tete Sambu, 2011)

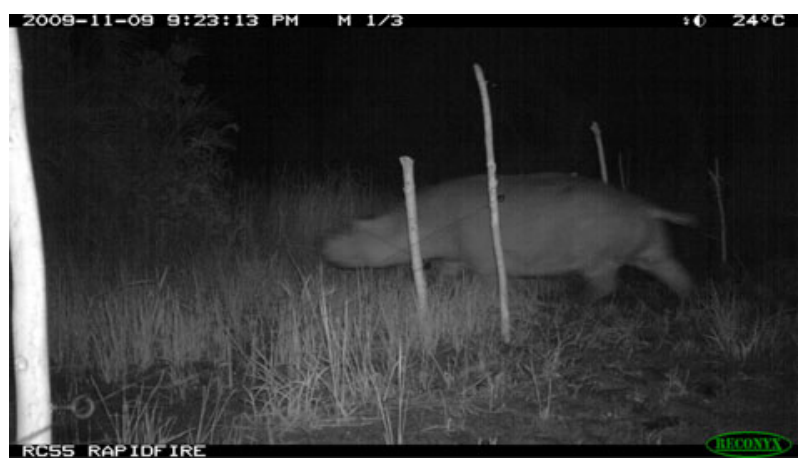

Plate 3 Camera trap images of a hippopotamus crossing an electric fence in a rice field in Acagume (Orango), in 2009.

significantly (from 135 in 2009 to 566 in 2011, $r^{2}=0.86, r=$ $0.92, \mathrm{P}=0.072)$.

\section{Hippopotamus behaviour}

Hippopotamuses entered the fields at night, except in one case where an individual was observed feeding during the day in an unfenced field (Plate 2). Although hippopotamuses were detected in 10 fenced fields, in nine of these the electric system was not operating because the surrounding vegetation was in contact with the wire or the wire was not connected to the energizer. After resetting the appropriate operating conditions we detected no more entries into these fields, although the hippopotamuses did make further attempts. Only in one field did an individual enter while the electric fencing was operating properly, and this same individual (as indicated by the marks on their skin, Plate 3), an adult male, entered the field $56.5 \%$ of the days surveyed $(n=56)$. The individual entered for the first time before the electric fence had been installed, and after installation entered by walking below the wire. After a second wire was installed the hippopotamus passed between the two wires, pushing one wire until the tension caused it to break, or breaking the wire by standing on it.

\section{Discussion}

Our results indicate that the frequent access of hippopotamuses to flooded rice fields resulted in significant damage to crops, confirming the information provided by farmers in previous studies (Lopes, 1998; Campos et al., 2001) and as occurred in other regions (Clarke, 1953; Mkanda, 1994; Kendall, 2011). In our study area, as in other regions (Verweij et al., 2006; Chansa et al., 2011), the dry and humid savannah grasslands are the preferred feeding grounds of the hippopotamus, and are the habitat that holds the greatest diversity and abundance of grass species. In our study area up to 70 species have been identified in the diet of the hippopotamus (Duarte et al., 200o). Much of the diversity and abundance of local grass species is maintained in the flooded rice fields (Catarino et al., 2008), which could explain why hippopotamuses are attracted to these areas. Hippopotamuses frequently enter flooded fields when the stem rice is in the vegetative growth phase, at the end of the rainy season and the beginning of the dry season, and also when the dry savannah grass begins to dry out and humid savannah grasses and stem rice in flooded fields are still green and growing (Catarino et al., 2001). The dry savannah grasses are found in the plains and are rarely inundated, whereas the humid or wet savannah are flooded during the wet season, with the dominant species being Anadelphia afzeliana (Duarte et al., 2000). Thus, the humid savannahs and the flooded rice fields established in them constitute a critical dry-season feeding ground for hippopotamuses, and could explain the high frequency of hippopotamuses entering these rice fields.

The lower frequency of hippopotamuses entering rain-fed fields compared to flooded fields is probably a result of rain-fed fields generally being located far from watercourses. In addition, in rain-fed fields vegetative stems grow earlier during the rainy season, when the greatest abundance of pasture is available in the dry savannahs. Thus, riceplanting dates, which determine the duration of the cultivation in each season, could be a factor in determining the extent of crop damage by hippopotamuses, and could be adjusted to minimize the amount of damage caused. In flooded fields, as in rain-fed fields, the dates for sowing seeds could be brought forward by using short-cycle seeds, to match the period of vegetative stem growth to that of the natural grasses in the hippopotamuses' feeding grounds.

Electric fencing produced a negative reaction in hippopotamuses because they tended to touch the wire with their noses, a poorly insulated and highly innervated part of the body (Eltringham, 1999). However, we observed one 
individual that crossed the electric fence while it was operating. It touched the wire with its neck, back or chest (Plate 3), which are less sensitive areas than the nose, and then moved swiftly, crossing before the electrical pulse was generated. We do not discard the possibility that this individual may have been tolerant to the level of shock intensity. The decrease in detection of hippopotamuses in fenced fields over the course of the study period may also indicate that damage was caused by a few individuals, who learned to avoid the fields after the electric fences were installed. Hippopotamuses may also have detected the electric fence without actually touching it; as has been suggested for domestic animals, they may have detected the odour, electromagnetic field or ozone generated around the wires (McKillop et al., 2003).

A potential ecological disadvantage of fenced fields is that fencing may be regarded as an incentive to transform humid savannahs to flooded rice fields, which could reduce hippopotamuses' access to dry-season grazing grounds. In this context, and considering that the grazing requirement, estimated in a subtropical ecosystem, is 6 ha of grassland per individual (Chansa et al., 2011), the hippopotamus population of Orango, estimated to be 150 individuals (Silva, 2008), requires 900 ha of grassland, which is less than the area of dry and humid savannahs available, estimated to be 7,020 ha (Cuq et al., 2001). The hippopotamus population is probably below its carrying capacity in Orango. Although hippopotamus populations are limited by food availability in the dry season (Lewison, 2007; Harrison et al., 2008), in Orango the savannahs are the most extensive habitat, occupying $27 \%$ of the surface area (Cuq et al., 2001), and have increased notably since the mid 2oth century (Vasconcelos et al., 2002). This could mitigate the effects of fencing in reducing hippopotamuses' access to flooded fields. However, we recommend an assessment of the impact of fencing flooded fields on the ecological requirements of hippopotamuses, especially during the dry season.

In the two protected areas the wildlife authorities donated the electric fencing to the farmers, who paid a small amount annually for maintenance and installation. With the fencing we observed that night watchmen were no longer necessary to protect the crops. There was a notable increase in the number of active flooded rice fields, rice production and the number of families working in the fields. For these reasons, in this case mitigation is more cost effective than compensation. In this context we recommend that further interviews are conducted with farmers to ascertain if the attitude of the local population towards hippopotamuses has improved following this study, and if the conflict has been mitigated.

Electric fences have been demonstrated to be useful in preventing crop raiding by megaherbivores in Africa. However, because of financial constraints, complex maintenance and the need for trained personnel they are of limited applicability in many countries (Lindsey et al., 2012). In our study there were no malfunctions of the electric equipment, and the few incidents detected were attributable to human factors and were easily resolved. The success of electric fencing as a deterrent was primarily a result of using a new energizer unit, which is portable, well suited to the various enclosure sizes and moisture conditions in the field, and its operation is simple and easily understood. Thus, based on our results we conclude that the electric fencing system, if used properly, is potentially an efficient and viable method of preventing the access of hippopotamuses and other megaherbivores into crop fields. However, electric fences should be designed to minimize the loss of wild animals as a result of entanglement or electrocution (Lindsey et al., 2012). As the components of electrified fencing are valuable and vulnerable to theft, their use should be restricted to smaller and well-surveyed protected areas where there are severe human-wildlife conflicts.

\section{Acknowledgements}

We thank the technicians of the Instituto da Biodiversidade e das Áreas Protegidas of Guinea-Bissau (IBAP), in particular the Director Alfredo Simão, and Justino Biai, Cristina Silva, Aissa Regalla, Antonio Da Silva, Domingozinho, Fernando Biagi, Januario Gomes, Domingos Betunde and Cecilia Netambo. We are also grateful to the wardens of Orango National Park and Tarrafes do Rio Cacheu Natural Park for their invaluable help. We especially thank Jose Eliseo Benante, Teté Sambú and Guerra Bidonga. We are grateful also to Pierre Campredon, Nelson Dias, John Sivhik and Kurt Verkauteren for providing technical assistance. Jean Paul Taris, Luc Hoffman, Ignacio Morillo, Mary Seck, Iris Cardiel, José Jiménez, Francisco Cantos, Miguel Angel Cedenilla, Sandra Agudín, Fernando Silvestre, Mercedes Muñoz and Cristina Martínez provided advice and logistical support throughout this study. We thank Rubén Moreno-Opo and Jaime Muñoz for comments and advice. Financial support for this study was provided by MAVA Foundation, Fundación Biodiversidad of Spain, O. A. Parques Nacionales, MAGRAMA and AECID Spain.

\section{References}

Alves, J. \& B Arros, A.E. (1997) Estudo de incidência sócio-económica da criação do Parque Nacional no Grupo de Ilhas de Orango. Gabinete de Planificação Costeira, IUCN, Bissau, Guinea-Bissau.

Biai, J.C.M. (2000) Análise das alterações das manchas de coberto vegetal nos Parques de Cacheu e Orango (Guiné-Bissau). Centro Nacional de Informação Geográfica, Lisbon, Portugal.

Campos, A., Monteiro, H., Soares, J. \& Catry, P. (2001) O Hipopótamo no Parque Nacional de Orango. IUCN, Bissau, Guinea-Bissau. 
Catarino, L., Duarte, M.C. \& Diniz, M.A. (2001) Aquatic and wetland plants in Guinea-Bissau: an overview. Systematics and Geography of Plants, 71, 197-208.

Catarino, L., Martins, E.S., Basto, M.F.P. \& Diniz, M.A. (2008) An annotated checklist of the vascular flora of Guinea-Bissau (West Africa). Blumea, 53, 1-222.

CCKP (Climate Change Knowledge Portal) (2015) Http:// sdwebx.worldbank.org/climateportal [accessed 5 January 2015].

Chansa, W., Senzota, R., Chabwela, H. \& Nyirenda, V. (2011) The influence of grass biomass production on hippopotamus population density distribution along the Luangwa River in Zambia. Journal of Ecology and the Natural Environment, 3, 186-194.

Clarke, J.R. (1953) The hippopotamus in Gambia, West Africa. Journal of Mammalogy, 34, 299-315.

Cuq, F., Campredon, P., Giraudet, J., Gourmelon, F., Pennoberg, D.A. \& Silva, A. (2001) Un Système d'Information Géographique pour l'aide à la gestion intégrée de l'archipel des Bijagos (Guinée-Bissau). Géosystèmes, Brest, France.

Duarte, M.C., Catarino, L. \& Romeiras, M.M. (2000) Aspectos fitogeográficos das gramíneas na Guiné-Bissau. Portugaliae Acta Biologica, 19, 429-442.

Eltringham, S.K. (1999) The Hippos. Academic Press, London, UK.

FunGO, B. (2011) A review crop raiding around protected areas: nature, control and research gaps. Environmental Research Journal, 5 , $87-92$.

Harrison, M.E., Kalindekafe, M.P. \& Banda, B. (2008) The ecology of the hippopotamus in Liwonde National Park, Malawi: implications for management. African Journal of Ecology, 46, 507514.

ibap (Instituto da Biodiversidade e das Áreas Protegidas) (2008) Plano de Gestao do Parque Natural dos Tarrafes do Río Cacheu. IBAP, Bissau, Guinea-Bissau.

iBaP (Instituto da Biodiversidade e das Áreas Protegidas) (2014) Estratégia Nacional para as Áreas Protegidas e a conservação da biodiversidade na Guiné-Bissau 2014-2020. IBAP, Bissau, Guinea-Bissau.

Kendall, C.J. (2011) The spatial and agricultural basis of crop raiding by the Vulnerable common hippopotamus Hippopotamus amphibius around Ruaha National Park, Tanzania. Oryx, 45, 28-34.

Lewison, R. (2007) Population responses to natural and human mediated disturbances: assessing the vulnerability of the common hippopotamus (Hippopotamus amphibius). African Journal of Ecology, 45, 407-415.

LeWison, R. \& Oliver, W. (2008) Hippopotamus amphibius. In IUCN Red List of Threatened Species v. 2012.1. Http://www.iucnredlist.org [accessed 5 July 2012].

LEWISON, R.L. \& CARTER, J. (2004) Exploring behavior of an unusual megaherbivore: a spatially explicit foraging model of the hippopotamus. Ecological Modelling, 171, 127-138.

Limoges, B. \& Robillard, M.J. (1991) Proposition d'un plan d'aménagement de la Réserve de la Biosphere de l'archipel des Bijagós. Vol. 2. Les espèces animales: distributions et recommandations. CECI/IUCN/MDRA, Bissau, Guinea-Bissau.
Lindsey, P.A., Masterson, C.L., Beck, A.L. \& Romañach, S. (2012) Ecological, social and financial issues related to fencing as a conservation tool in Africa. In Fencing for Conservation: Restriction of Evolutionary Potential or a Riposte to Threatening Processes (eds M. J. Somers \& M.W. Hayward), pp. 215-234. Springer, New York, USA.

Lopes, A.J. (1998) Estudo da populaçao de hipopotamos no Parque natural des tarrafes do Rio Cacheu e zones adjacentes e Suzana e Varela. IUCN, Bissau, Guinea-Bissau.

McKillop, I.G., Pepper, H.W., Butt, R. \& Poole, D.W. (2003) Electric Fence Reference Manual. Research and Development Surveillance Report 607. Defra, London, UK.

Medina, N. (2008) O ecossistema orizícola na Guiné-Bissau: principais constrangimentos à produção na zona I (regiões de Biombo, Cacheu e Oio) e perspectivas. MSc thesis. Universidade Técnica de Lisboa, Lisbon, Portugal.

Michez, A. (2006) Etude de la population d'hippopotames (Hippopotamus amphibius) de la rivière Mouena Mouele au Parc National du Loango-Sud (Gabon). MSc thesis. Gembloux Agro-Bio Tech, Université de Liège, Gembloux, Belgium.

Mkanda, F.X. (1994) Conflicts between hippopotamus (Hippopotamus amphibious (L.)) and man in Malawi. African Journal of Ecology, 32, 75-79.

Silva, C. (2008) Recenseamento annual da popolaçao de Hippopotamus amphibius no PNO e Ilha de Uno. IBAP/IUCN, Bissau, Guinea-Bissau.

Silva, C. \& Monteiro, H. (2006) Missao de avaliaçao do impacte de hipopotamos nas bolanhas de Carantaba e Bissora. IBAP/IUCN, Bissau, Guinea-Bissau.

StatSoft (2002) Statistica v. 6.1. Http://www.statsoft.com [accessed 11 March 2014].

Vasconcelos, M.J.P., Biai, J.C.M., Araújo, A. \& Diniz, M.A. (2002) Land cover change in two protected areas of Guinea-Bissau (19561998). Applied Geography, 22, 139-156.

Verweij, R.J.T., Verrelst, J., Loth, P.E., Heitkönig, I.M.A. \& BRUnsting, A.M.H. (2006) Grazing lawns contribute to the subsistence of mesoherbivores on dystrophic savannas. Oikos, 114, 108-116.

Woodroffe, R., Thirgood, S. \& Rabinowitz, A. (eds) (2005) People and Wildlife: Conflict or Coexistence? Cambridge University Press, Cambridge, UK.

\section{Biographical sketches}

Luis M. González and Francisco G. D. Montoto conduct research on threatened species, human-wildlife conflict and biodiversity conservation. Tome Mereck, Junior Alves and José Pereira work on wildlife monitoring and sustainability projects for biodiversity conservation in Guinea-Bissau. Pablo Fernández de Larrinoa, Ana Maroto and Nuria EL-Kadhir work on threatened species and on a variety of sustainability projects for biodiversity conservation and livelihood improvement in African countries. LUIS Bolonio studies the ecology and conservation of threatened birds. 